\title{
Removal of Turbidity, Suspended Solids and Ions of Fe from Aqueous Solution using Okra Powder by Coagulation-Flocculation Process
}

\author{
Edilson de Jesus ${ }^{1, *}$, Paulo Victor Cruz ${ }^{1}$, José Adair Pacífico ${ }^{1}$, Antônio Santos Silva ${ }^{2}$ \\ ${ }^{1}$ Departament of Chemical Engineering, Federal of Sergipe University, São Cristóvão-SE, Brazil \\ ${ }^{2}$ Departament of Mathmatics, Federal of Sergipe University, São Cristóvão-SE, Brazil \\ *Corresponding author: edilsonjs@ufs.br
}

Received April 16, 2013; Revised June 26, 2013; Accepted June 27, 2013

\begin{abstract}
This work evaluates the efficiency of okra powder in removing turbidity, suspended solids and ions of Fe from synthetic raw water through coagulation-flocculation process. The raw water samples with initial turbidity of 100 NTU were prepared using natural red clay $(-32+100$ mesh particle size). The jar tests were carried out by varying the $\mathrm{pH}$ and the dose of okra powder. The initial $\mathrm{pH} 8.0$ of synthetic raw water and $30 \mathrm{mgL}^{-1}$ okra powder caused $80.92 \%$ reduction of Fe ions and $99 \%$ turbidity removal after 10 minutes of sedimentation. The efficiency of Fe the removal was evaluated by characterization EDX sludge formed after sedimentation with and without okra powder and the jar tests were carried out using a solution of ferric sulfate as the coagulating agent.
\end{abstract}

Keywords: coagulation-flocculation, okra powder, ions of Fe, suspended solids, turbidity

\section{Introduction}

Water treatment is the removal of suspended solids and microorganisms present in the water, always seeking lower operational and environmental costs [1]. Water and wastewater treatment methods include coagulationflocculation, flotation, sedimentation, filtration, membrane process, electrochemical techniques, ion exchange and biological processes. Several biodegradable materials have been used to remove pollutants from the different industrial effluents for their safe disposal into the biosphere [2].

Coagulation aims at agglomerating suspended and colloidal materials so that they can be removed by sedimentation and filtration. The phenomenon of agglomeration occurs due to a destabilization induced by the addition of coagulants neutralizing the electrical forces. Surface nullifies the repulsive forces favoring the formation of larger flocs that settle [1]. Gentle agitation is used in the flocculation facilitating contact the flocs but avoiding them breaking. The flocs grow by adsorption of suspended particles or colloidal state.

The process efficiency depends on several factors. The main factors relate to station design, use of new technologies and procedures to reduce the costs involved in the treatment, such as the use of natural polymers that reduce the consumption of coagulant agents and favor the flocs formation.

Turbidity, suspended solids and color removal are important steps in the water treatment process, which is generally achieved by using coagulant agents. The two primary coagulants most commonly used include aluminum and iron (III) salts [3]. However, recent studies have pointed out several drawbacks of using aluminum salts, such as the Alzheimer's disease associated with residual aluminum in treated water and production of large sludge volumes [4].

The use of polymers as flocculation auxiliary enables more efficient removal of suspended solids of water [5]. These polymers may be synthetic or natural. Synthetic polymers present known formulation and have long chains capable of establishing bonds between small particles finely dispersed in water enabling the formation of agglomerates. Therefore, load, polymer molecular weight and the functional group are of fundamental importance [6].

The natural polymers do not harm the environment. Biomass products have been used in water treatment and wastewater due to their biodegradability. With regard to the adsorption, various types of biomass such as chitosan, charcoal, sugarcane bagasse, dead fungal biomass, green algae and cyanobacteria were used for chromium removal [7-15].

Okra is a perennial shrub plant, erect and a semi-woody stem, which can reach three meters in height $[16,17]$. Belonging to the family of Malvaceae, it constitutes as a crop of fast vegetative cycle, easy grow and high yield [18]. The Abelmoschus genus accounts for 10 known species and difficult to distinguish. In Brazil, the three largest producers are the states of Minas Gerais, São Paulo and Sergipe. In Sergipe, the most common species are and Abelmoschus esculentum and Abelmoschus caillei, which are cropped for their fruits.

The fruit of okra is a capsule filled with viscous white mucus and round seeds of high nutritional value and used as a complete source of fibers, calcium, minerals and 
vitamins [19]. The seeds account for $17 \%$ of the fruit and consist of oils (which can account for $40 \%$ ) and proteins ( $>15 \%$ ) with mean duration of 5 years germline [20]. For all cultivars of okra analyzed in [20], the starch levels ranged from 0.98 to $1.23 \%$ and the carbohydrate levels from 1.91 to $2.16 \%$ on fresh weight. Moreover, the seeds contain polyphenolic compounds, mostly atequins derivatives and oligomeric flavonoids [21].

The okra powder is natural organic matter, therefore comprises hydrophilic colloids, low-molecular weight acids, proteins, polysaccharides, humic acids and fulvic acids. These polysaccharides (natural polymers) are effective for synthetic flocculants [15,22]. The main advantage of using okra powder is its natural composition. In addition, the powder may be produced from mature fruits often rejected by consumers. Among the main disadvantages is the increased organic matter in the water, which can increase the amount of oxidants.

In this work, okra powder was used for removing impurities from raw water. It is expected further reduction of suspended solids, turbidity and content of iron ions in the treated water; the $\mathrm{pH}$ and dose of okra powder influence the process of reduction and the presence of iron ions in the sludge formed is higher when using okra powder. This paper seeks a cleaner procedure that does not harm the environment.

\section{Materials and Methods}

\subsection{Preparation of Synthetic Water}

The synthetic water was prepared from weighing $1 \mathrm{~g}$ of natural red clay $(-32+100$ mesh particle size) resulting in colloidal suspended solids important to turbidity formation and enable the iron determination in the clay before treatment. Turbidity in the experiments was 100 NTU and $\mathrm{pH}$ 7.0. For $\mathrm{pH}$ adjustments, 0.05 molar $\mathrm{NaOH} / 0.1$ molar $\mathrm{H}_{2} \mathrm{SO}_{4}$ was used. The turbidity analysis was carried out using the nephelometric method on turbidimeter model AP 2000 and the $\mathrm{pH}$ was measured by a Politerm pHmeter.

\subsection{Preparation of Okra Powder}

The okra pods were dried in the greenhouse Sterilifer model SX 1.0 at $150^{\circ} \mathrm{C}$ for 4 hours for obtaining the okra powder. After drying, okra pods were ground in common food processor. The granulometric classification of okra powder (50 g) was determined into stirrer of Bertel sieves of different mesh openings. Okra powder with 32 mesh (12+32 mesh) particle size was used for the coagulationflocculation experiments.

\subsection{Analysis of Ions Fe Removal Using UV- VIS Spectrophotometry through Complexation with Phenanthroline}

The experiments for Fe removal were performed using the jar test model JT 102.3 of Milan and consisted of three steps: rapid mixing, slow mixing and sedimentation. One liter synthetic raw water was submitted to the Jar test for 1 minute rapid mixing at $150 \mathrm{rpm}$. In the rapid mixing there was addition of $2.5 \mathrm{~mL}$ of ferric sulphate at $0.05 \mathrm{~g} \mathrm{~mL}^{-1}$ in $1 \mathrm{~L}$ synthetic raw water. It is equivalent to a dosage of
$125 \mathrm{gL}^{-1}$ allowing the coagulant homogenization in the samples and the emergence of the first flocs. Subsequently, the stirring speed was reduced to $30 \mathrm{rpm}$ (slow mixing) for 15 minutes allowing the growth of flocs. The okra powder addition was performed at the beginning of slow mixing. After slow mixing, the sedimentation of flocs was performed for 15 minutes.

The design of experiments called central composite [23] was used to study the effect of okra powder dosage and the synthetic water $\mathrm{pH}$ on the iron removal. Okra powder dosages used were 5.86, 10, 20, 30 and $34.14 \mathrm{mgL}^{-1}$. The determination of iron ions was according the Standard Methods for the Examination of Water and Wastewater [24] by spectrophotometric method making use of a Cary Model UV-visible spectrophotometer. Absorbance was measured at $540 \mathrm{~nm}$ wavelength.

The determination of iron ions concentration was performed after the initial addition of coagulant during rapid mixing by collecting $10 \mathrm{~mL}$ water. The final iron ions concentration was measured after slow mixing. Equation 1 was used to calculate the iron removal.

$$
\% \mathrm{Fe}(I I I) \text { removal }=\frac{\mathrm{C}_{\mathrm{i}}-\mathrm{C}_{\mathrm{f}}}{\mathrm{C}_{\mathrm{i}}} \times 1000
$$

Where: $C_{f}$ is the final concentration and $C_{i}$ the initial concentration of iron ions.

$$
\text { Abs }=0.26003 C-0.03104
$$

Equation 2 was used to determine the concentration of iron ions with determination coefficient of $\mathrm{R}^{2}=0.9868$, where $\mathrm{C}$ is the concentration of iron and Abs is the absorbance.

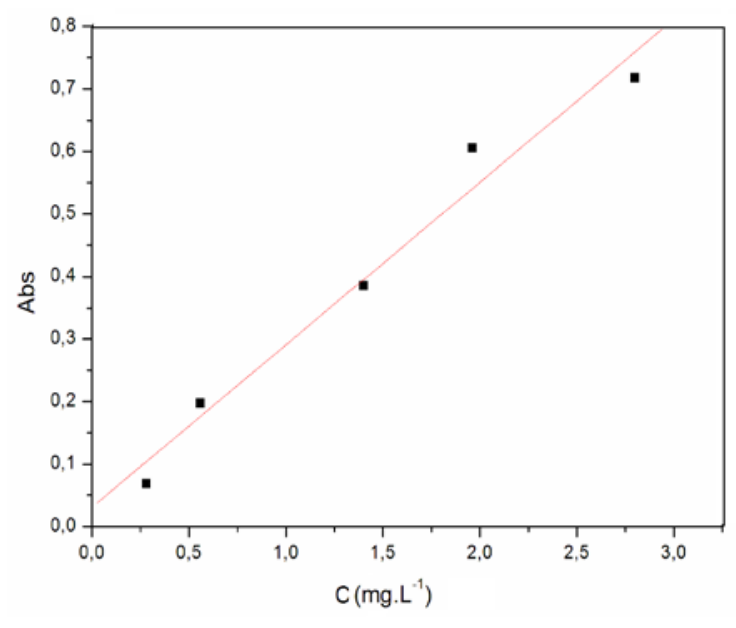

Figure 1. Calibration curve for determination of Fe concentration

The procedures of coagulation, flocculation and sedimentation afore described were used. The concentrations of standard iron solution prepared for the calibration curve were $0.28,0.56,1.40,1.96,2.80 \mathrm{mgL}^{-1}$ using $\mathrm{FeSO}_{4} \cdot\left(\mathrm{NH}_{4}\right)_{2} \mathrm{SO}_{4} 6 \mathrm{H}_{2} \mathrm{O}$. Figure 1 shows the calibration curve for determining the Fe in the samples.

\subsection{Analysis Remaining Turbidity}

The samples were submitted to the Jar test for 1 minute of rapid mixing at $150 \mathrm{rpm}$. $2.5 \mathrm{~mL}$ ferric sulphate at 0.05 $\mathrm{g} \mathrm{mL}^{-1}$ was added to $1 \mathrm{~L}$ synthetic raw water in the rapid mixing for coagulant homogenization in the samples and the appearing of the first flocs. Subsequently, there was reduction in the stirring speed $(30 \mathrm{rpm})$ for 15 minutes. 
The sedimentation phase of flocs started after the slow mixing and lasted 15 minutes. Two decay curves of turbidity at 2-minute intervals were carried out. Two experiments were conducted: one with $30 \mathrm{mgL}^{-1}$ okra powder and another without powder okra and $\mathrm{pH}$ 8.0. Samples were collected at 2-minute intervals after coagulation and flocculation. The collection was always performed $2 \mathrm{~cm}$ below water surface. Turbidity was measured by the nephelometric method using a turbidimeter model AP2000. Each experiment was carried out in triplicate.

\subsection{Analysis of Removing Suspended Solids}

For determination of suspended solids were used the Standard Methods for the Examination of Water and Wastewater [24]. The experiments were performed using the Jar test model JT 102.3 of Milan. The samples were submitted to the Jar test for 1-minute rapid mixing at 150 rpm. During rapid mixing $2.5 \mathrm{~mL}$ of ferric sulphate at 0.05 $\mathrm{g} \mathrm{mL}^{-1}$ were added to $1 \mathrm{~L}$ synthetic raw water for coagulant homogenization in the samples and the emergence of the first flocs. Subsequently, the stirring speed was reduced to $30 \mathrm{rpm}$ (slow mixing) for 15 minutes allowing the growth of flocs. The addition of okra powder was performed at the beginning of slow mixing. After slow mixing, the sedimentation phase of flocs lasted 15 minutes. This analysis was conducted in the experiments with okra powder at $30 \mathrm{mgL}^{-1}$ and without okra powder and pH 8.0. After each test, $200 \mathrm{~mL}$ water was collected for analysis of suspended solids. Each experiment was performed in triplicate.

\subsection{Absorption Spectroscopy in the Infrared Region of Okra Powder}

Infrared spectra of samples of clay, okra powder and sludge were obtained on a FTIR spectrophotometer FT-IR Spectrum Bx system from Perkin Elmer in the region between 4000 and $400 \mathrm{~cm}^{-1}$ with $4 \mathrm{~cm}^{-1}$ resolution. Samples were analyzed as $\mathrm{KBr}$ pellets with nujol.

\subsection{X-Ray Fluorescence}

The chemical composition of okra powder, clay and silt formed was determined by X-ray fluorescence using the EDX-700 of Shimadzu and the working atmosphere was air. The excitation energy used were $50 \mathrm{keV}$ and 20. The sample was placed into a cuvette and covered with a polypropylene film of five microns thickness. This analysis was performed to check the powder efficiency for Fe removal.

\section{Results and Discussion}

\subsection{Effect of Dose of Okra Powder and pH at Iron Ions Removal}

Central composite design was used to study the dose effect of okra powder and synthetic water $\mathrm{pH}$ on the $\mathrm{Fe}$ removal.

The experiments performed are shown in Table 1 . The iron removal was calculated by Equation 1.
Table 1. Experimental design (Central composite design)

\begin{tabular}{|c|c|c|}
\hline $\begin{array}{c}\text { Okra powder } \\
\text { dose } \mathrm{mgL}^{-1}\end{array}$ & Raw water $\mathrm{pH}$ & \% Fe removal \\
\hline 10 & 6.0 & 16.51 \\
\hline 10 & 8.0 & 33.57 \\
\hline 30 & 6.0 & 14.15 \\
\hline 30 & 8.0 & 80.92 \\
\hline 5.86 & 7.0 & 25.16 \\
\hline 34.14 & 7.0 & 50.16 \\
\hline 20 & 5.6 & 23.05 \\
\hline 20 & 8.4 & 80.62 \\
\hline 20 & 7.0 & 50.02 \\
\hline 20 & 7.0 & 51.54 \\
\hline 20 & 7.0 & 52.86 \\
\hline
\end{tabular}

Table 2. Variance analysis(ANOVA) of the experimental design

\begin{tabular}{|c|c|c|c|c|c|}
\hline Factor & SS & DF & MS & F & p \\
\hline $\mathrm{C}(\mathrm{L})$ & 806.922 & 1 & 806.922 & 25.2931 & 0.004003 \\
\hline $\mathrm{pH}(\mathrm{L})$ & 3413.291 & 1 & 3413.291 & 106.9902 & 0.000145 \\
\hline 1Lby 2L & 617.771 & 1 & 617.771 & 19.3641 & 0.007019 \\
\hline Error & 159.514 & 5 & 159.514 & - & - \\
\hline Sum SS & 5460.313 & 10 & - & - & - \\
\hline
\end{tabular}

Table 2 shows the analysis of variance (ANOVA) results for Fe removal from raw water. It is possible to check whether the linear term of $\mathrm{pH}$ ( $\mathrm{p}$-value equal to 0.000145 ) and the linear term of okra powder dosage (pvalue equal to 0.004003) are significant for removal of iron ions ( $p<0.05$ ). The correlation coefficient of the relationship between removal of iron and the factors $\mathrm{pH}$ and dose was approximately 0.90 . Analysis of variance was performed in the software Statistica 8.0 (StatSoft Company). The highest removal of Fe occurred at $\mathrm{pH} 8.0$ and $30 \mathrm{mgL}^{-1}$ okra powder as shown in Table 1.

The okra powder has characteristic groups such as carboxyl that serves as active sites for attachment of colloidal particles and metal ion. Results from the literature show that the percentage of metals removal by the biosorbents heavily depends on $\mathrm{pH}$. Removal of $\mathrm{Cr}$ (VI) increased from $70 \%$ to $78 \%$ when $\mathrm{pH}$ ranged from 1.5 to 2.0 using $0.1 \mathrm{~g}$ Osage orange as biosorbent [14].

\subsection{Analysis on the Remaining Turbidity}

Figure 2 shows that okra powder decreased turbidity from $100 \mathrm{NTU}$ to $25 \mathrm{NTU}$ in 1 minute (75 \% turbidity removal). Without using the okra powder turbidity removal was $5 \%$ in 1 minute. The okra powder, composed of polysaccharides, protein and fats [16], favors the interactions among clay, metal species and okra powder, explained by the electrostatic attraction, chemical bonding or ion exchange [25,26], once clay minerals are formed more frequently. The colloidal particles of natural clays have electrical properties that create a repulsive force preventing agglomeration and sedimentation. Thus, their characteristics need to be changed to cause flocculation. The use of okra powder rich in proteins, fats and polysaccharides showed to be a promising flocculation tool for increasing the availability of active sites capable of adsorbing metallic species during the coagulationflocculation process. 


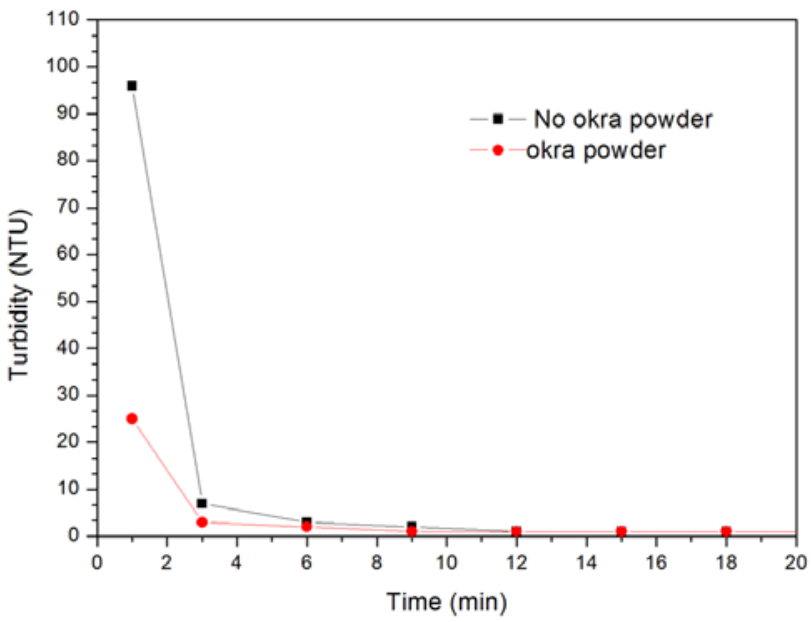

Figure 2. Curve for remaining turbidity after treatment with and without okra powder.

\subsection{Analysis of Suspended Solids Removal}

The use of powder okra favored a greater removal of suspended solids. This action is also explained by the process of electrostatic attraction of powder and suspended particles. The average amount of suspended solids was $7 \mathrm{mgL}^{-1}$ when using okra powder and $26 \mathrm{mgL}^{-1}$ without using it.

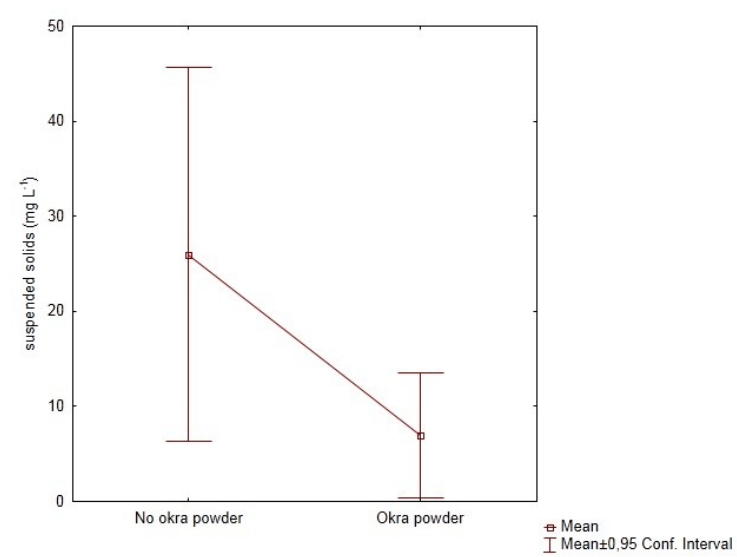

Figure 3. Mean removal of suspended solids after treatment with and without okra.

Figure 3 shows the confidence intervals around the mean removal of suspended solids.

The okra powder is composed of organic substances that account for groups such as polyphenol and carboxyl and serves as actives sites for binding the metal ion [28]. For being rich in phenolic compounds and carboxylic, it can behave as active sites [14] for binding Fe(III) [27], favoring the formation of flocs and causing reduction of suspended solids.

\subsection{Infrared Analysis (FTIR)}

Spectroscopic data recorded in the absorption spectrum in the infrared region.

The adsorption occurs due to the presence of functional groups comprising the adsorbent material. The infrared spectroscopy was used for determining these groups.

Figure 4, allowed assigning characteristics compatible with polysaccharide substances to product obtained from okra drying. The variable bands around 1373 were assigned to bending vibration of the $-\mathrm{C}-\mathrm{H}$ - of alkil group [28]. The absorption peaks for okra powder that appear in the region of $1645 \mathrm{~cm}^{-1}$ indicates carbonyl of carboxyl acid and the larger band in the region near $3400 \mathrm{~cm}^{-1}$ is indication stretching of the hydroxyl groups $(-\mathrm{OH})$ carboxyl acid. These groups serve as active sites for attachment of colloidal particles and metal ion.

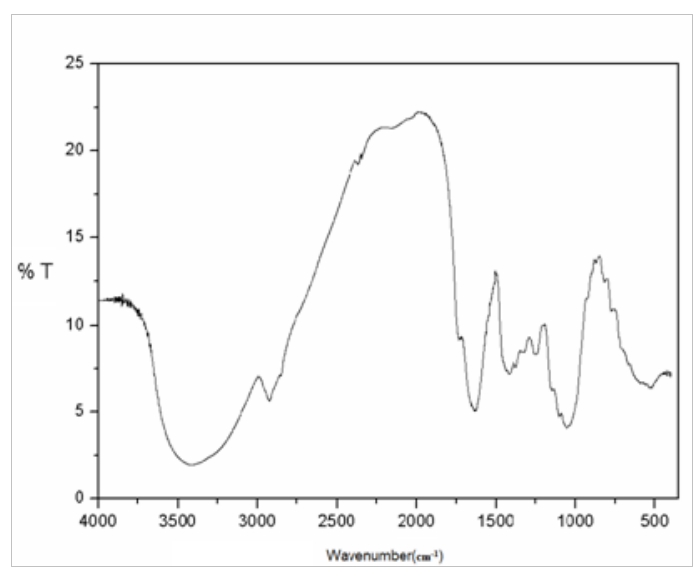

Figure 4. FTIR spectra of okra powder

The adsorption of colloidal particles on the surface of polymers occurs by coulombic interaction (charge-charge) through hydrogen bonds, van der Waals interactions or a combination thereof. The adsorbed polymers can both stabilize and destabilize depending mainly on the amount of polymer and particles, the affinity between the polymer particle and water and the type and concentration of electrolytes [29].

\subsection{X-Ray Fluorescence}

Table 3 shows the results of analysis by X-rays fluorescence evidencing that clay is mainly composed of $\mathrm{Al}_{2} \mathrm{O}_{3}$ (36.54\%), $\mathrm{Fe}_{2} \mathrm{O}_{3}$ (5.66\%) and $\mathrm{SiO}_{2}$ (54.59\%), while mineral clays are formed most often by the following elements: oxygen, silicon, aluminum, iron, magnesium, calcium, potassium and sodium.

Table 3. Results for EDX analysis of clay, okra powder and sludge with okra powder

\begin{tabular}{|c|c|c|c|c|}
\hline Oxides & Clay & $\begin{array}{c}\text { Okra } \\
\text { powder }\end{array}$ & $\begin{array}{c}\text { Sludge with } \\
\text { okra powder }\end{array}$ & $\begin{array}{c}\text { Sludge without } \\
\text { okra powder }\end{array}$ \\
\hline $\mathrm{Al}_{2} \mathrm{O}_{3}$ & 36.54 & - & 32.20 & 32.50 \\
\hline $\mathrm{Fe}_{2} \mathrm{O}_{3}$ & 5.67 & 0.40 & 12.30 & 9.80 \\
\hline $\mathrm{SiO} 2$ & 54.59 & - & 51.30 & 52.80 \\
\hline
\end{tabular}

The sludge obtained without using powder okra presented 9.8\% $\mathrm{Fe}_{2} \mathrm{O}_{3}$ while the sludge with okra showed $12.3 \% \mathrm{Fe}_{2} \mathrm{O}_{3}$. The removal of iron ions was higher when using okra powder. The okra powder composed of polysaccharides favors the interactions among clay, metal species and okra powder, which can be explained by the phenomenology of electrostatic attraction, chemical bonding or ion exchange [27,28,29,30].

\section{Conclusion}

The mature okra, dried and pulverized, is the simplest form for application as biopolymer in water treatment such as flocculation tools. The okra powder was effective in removing turbidity, reaching $99 \%$ after 10 minutes of 
sludge sedimentation. The experimental design showed $80.92 \%$ iron ions removal at $\mathrm{pH} 8.0$ and $30 \mathrm{mgL}^{-1}$ okra powder. The removal of suspended solids was more efficient when using the okra powder. Therefore, the okra powder was shown to be a very efficient flocculating auxiliary.

\section{Acknowledgement}

The authors wish to thank the Federal University of Sergipe by support in the execution of this article.

\section{References}

[1] Libânio M. Fundamentos de qualidade e tratamento de água. Átomo, Campinas, 2005.

[2] Akhtar M., Iqbal S., Bhanger M.I., Zia-Ul-Haq M., Moazzam M. "Sorption of organophosphorous pesticides onto chickpea husk from aqueous solutions”. Colloids Surf B Biointerfaces, 69:63-70, 2009.

[3] Okuda T., Baes A.U., Nishijima W., Okada M. "Improvement of extraction method of coagulation active components from Moringa oleifera seed”. Water Res, 33(15): 3373-3378, 1999.

[4] Ndabigengesere A., Narasiah K.S. "Quality of water treated by coagulation using Moringa oleifera seeds”. Water Res, 32:781-91, 1998.

[5] Zeng D., Wu J.; Kennedy J.F. "Application of a chitosan flocculant to water treatment”. Carbohydr Polym, 71:135-9, 2008.

[6] Santos Filho J.D., Santa Rita E.S. Gerenciamento do resíduo gerado na clarificação de água da RLAM [monograph on the internet]. Universidade Federal da Bahia (Escola Politécnica): Pós-Graduação em Gerenciamento e Tecnologia Ambientais na Indústria; 2008 [cited 2012 set 22]: Available from: http://www.teclim.ufba.br/site/material_online/monografias/mono _santosfilho_e_rita.pdf.

[7] Gupta V.K., Ali I. "Removal of lead and chromium from wastewater using bagasse fly ash-a sugar industry waste”. J Colloid Interface Sci, 271(2):321-8, 2004.

[8] Gupta V.K., Gupta M., Sharma S. "Process development for the removal of lead and chromium from aqueous solutions using red mud—an aluminium industry waste”, Water Res, 35:1125-34, 2001.

[9] Gupta V.K., Rastogi A. "Sorption and desorption studies of chromium (VI) from nonviable cyanobacterium Nostoc muscorum biomass”. J Hazard Mater, 154: 347-54, 2008.

[10] Gupta V.K., Rastogi A. "Biosorption of lead (II) from aqueous solutions by non-living algal biomass Oedogonium sp. and Nostoc sp.- - comparative study", Colloids Surf B Biointerfaces, 64:1708, 2008.

[11] Gupta V.K., Rastogi A. "Equilibrium and kinetic modelling of cadmium (II) biosorption by nonliving algal biomass Oedogonium sp. from aqueous phase”, J. Hazard Mater, 153:759-66, 208.

[12] Gupta V.K., Rastogi A. "Biosorption of lead from aqueous solutions by green algae Spirogyra species: kinetics and equilibrium studies”, J Hazard Mater, 152:407-14, 2008.
[13] Singh A.K., Gupta V.K., Gupta B. "Chromium (III) selective membrane sensors based on Schiff bases as chelating ionophores". Anal Chim Acta, 585:171-8, 2007.

[14] Pehlivan E., Kahraman H.T. Hexavalent chromium removal by Osage Orange, Food Chem, 133:1478-84, 2012.

[15] Agarwal M., Srinivasan R., Mishira A. "Study on flocculation efficiency of okra gum in sewage waste water", Macromol Mater and Eng, 286:560-3, 2001.

[16] Calixto C.D. Óleo de quiabo como fonte alternativa para produção de biodiesel e avaliação de antioxidantes naturais em biodiesel etílico de soja [monograph on the internet]. Universidade Federal da Paraíba: Programa de Pós-Graduação em Química; 2011 [cited 2012 oct 22]: Available from: http://www.quimica.ufpb.br/posgrad/dissertacoes/Dissertacao_Cle diana_Dantas_Calixto.pdf.

[17] FILGUEIRA, F. A. R. Novo Manual de Olericultura: agrotecnologia moderna na produção e comercialização de hortaliças - Viçosa: UFV, cap.24, p.337-382, 2000.

[18] COSTA, M.C.B; OLIVEIRA, G.D.; HAAG, H.P. Nutrição mineral de hortaliças - Efeito da omissão dos macronutrientes e do boro, no desenvolvimento e na composição química de hortaliças. In: HAAG, H. P.; MINAMI, K.; Nutrição mineral em hortaliças. Campinas: Fundação Cargill, 1981, cap. 6, p.257-276.

[19] Pedrosa J.F., Mizubuti A., Casali V.W.D., Campos J.P. "Caracterização Morfológica de Introduções de Quiabeiro (Abelmoschus esculentus (L.) Moench)”. Horticultura Brasileira, 1:14-23, 1983.

[20] MOTA, W.F.; FINGER, F.L.; SILVA, D.J.H.; CORRÊA, P.C.; FIRME, L.P.; NEVES, L.L.M. "Caracterização físico-química de frutos de quatro cultivares de quiabo". Horticultura Brasileira, Brasília, v.23, n.3, 722-725, 2005.

[21] Arapitsas P. "Identification and Quantification of Polyphenolic Compounds from Okra Seeds and Skins”. Food Chem, 110:104145, 2008.

[22] Agarwal M., Rajani S., Mishra A., Rai J. "Utilization of okra gum for treatment of tannery effluent". International Journal of Polymeric Materials, 52:1049-57, 2003.

[23] Calado V., Montgomery D.C. Planejamento de Experimentos Usando o Statistica. E-papers, Rio de Janeiro, 2010.

[24] Standard Methods for the Examination of Water and Wastewater, 21rd ed., Washington: American Public Heath Association, 2005.

[25] Shukla D., Vankar, S. "Efficient biosorption of chromium (VI) ion by dry Araucaria leaves”. Environ Sci Pollut Res, 19(6):2321-28, 2012.

[26] Santhana A., Kumar K., Kalidhasan S., Rajesh V., Rajesh N. "Application of Cellulose-Clay Composite Biosorbent toward the Effective Adsorption and Removal of Chromium from Industrial Wastewater”. Ind Eng Chem Res, 51:58-69, 2012.

[27] Marshall W.E, Champagne E.T. "Agricultural byproducts as adsorbents for metal ions in laboratory prepared solutions and in manufacturing wastewater”. J Environ Sci Health A, 30(2): 24161, 1995.

[28] Altun T., Pehlivan E. "Removal of $\mathrm{Cr}(\mathrm{VI})$ from aqueous solutions by modifield walnud shells”. Food Chem, 132:693-700, 2012.

[29] Bernardo L. Métodos e Técnicas de Tratamento de Água. ABES, Rio de Janeiro, 1993.

[30] Pehlivan E., Cetin S., Yanik B.H. "Equilibrium studies for the sorption of zinc and copper from aqueous solutions using sugar beet pulp and fly ash”. Journal Hazar Mater, 135(1):193-9, 2006. 